\title{
Tobacco Smoke Exposure in Pulmonary Arterial and Thromboembolic Pulmonary Hypertension
}

\author{
Stephan Keusch ${ }^{a}$ Florian F. Hildenbrand ${ }^{a}$ Tom Bollmann $^{b}$ Michael Halank ${ }^{c}$ \\ Matthias Held $^{d}$ Ralf Kaiser ${ }^{\mathrm{e}}$ Gabor Kovacs $^{\text {h, }}{ }^{\mathrm{i}}$ Tobias J. Lange $^{f}$ \\ Hans-Jürgen Seyfarth ${ }^{g}$ Rudolf Speich ${ }^{a}$ Silvia Ulrich ${ }^{a}$ \\ ${ }^{a}$ Clinic for Pulmonology and Internal Medicine, University Hospital of Zurich, Zurich, Switzerland; ${ }^{b}$ Department \\ of Internal Medicine B - Cardiology, Intensive Care, Pulmonary Medicine and Infectious Diseases, University of \\ Greifswald, Greifswald, 'Internal Medicine I, University of Dresden, Dresden, ${ }^{\mathrm{d} C l i n i c}$ for Pulmonology, University \\ of Würzburg, Würzburg, ${ }^{e}$ Clinic for Pulmonology, University of Homburg, Homburg, ${ }^{\mathrm{f}}$ Division of Pneumology, \\ Department of Internal Medicine II, University Medical Centre Regensburg, Regensburg, and ${ }^{9}$ Department of

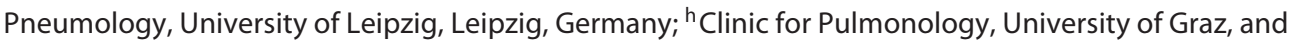 \\ 'Ludwig Boltzmann Institute for Lung Vascular Research, Graz, Austria
}

\section{Key Words}

Chronic thromboembolic pulmonary hypertension .

Pulmonary hypertension - Pulmonary arterial hypertension .

Tobacco smoke $\cdot$ Smoking $\cdot$ Risk factor

\begin{abstract}
Background: Animal studies and data from a single-center study suggest that tobacco smoke exposure may be a risk factor for precapillary pulmonary hypertension (PH). Objective: We aimed to survey tobacco smoke exposure in a large $\mathrm{PH}$ collective and to compare it with epidemiological data from healthy subjects. Methods: This is an international, multicenter, case-control study including patients with pulmonary arterial and chronic thromboembolic PH. All patients were asked specific questions about tobacco smoke exposure. Healthy controls were retrieved from the Swiss Health Survey $(n=18,747)$. Results: Overall $(n=472), 49 \%$ of $\mathrm{PH}$ patients were smokers and there was a clear sex difference (women $37 \%$, men $71 \%$ ). Significantly more PH men
\end{abstract}

were smokers compared with healthy controls, whereas less $\mathrm{PH}$ women were ever active smokers. However, $50 \%$ of the non-smoking $\mathrm{PH}$ women were exposed to secondhand smoke, leading to a significantly higher number of tobacco smoke-exposed individuals compared to healthy controls. $\mathrm{PH}$ smokers were significantly younger compared to those not exposed. Conclusion: Active and environmental tobacco smoke exposure is common in $\mathrm{PH}$. The higher prevalence of male PH smokers, the higher exposure to environmental tobacco smoke in $\mathrm{PH}$ women compared to healthy controls and the lower age at $\mathrm{PH}$ diagnosis in smokers may indicate a pathogenic role of tobacco smoke exposure in $\mathrm{PH}$.

(c) 2014 S. Karger AG, Basel

\section{Introduction}

Precapillary pulmonary hypertension $(\mathrm{PH})$ has been defined as a mean pulmonary artery pressure (mPAP) $\geq 25 \mathrm{~mm} \mathrm{Hg}$ along with a pulmonary artery wedge pres-

\section{KARGER}

E-Mail karger@karger.com www.karger.com/res
(C) 2014 S. Karger AG, Basel

$0025-7931 / 14 / 0881-0038 \$ 39.50 / 0$ 
sure $\leq 15 \mathrm{~mm} \mathrm{Hg}$ (to differentiate from pulmonary venous hypertension due to left heart disease). $\mathrm{PH}$ is either idiopathic or associated with many different disorders, such as collagen vascular disease, portal hypertension, hypoxemic lung diseases, chronic thromboembolism and many more [1]. The pathophysiology of $\mathrm{PH}$ is still incompletely understood. It is thought that excessive vasoconstriction possibly in combination with inflammation may lead to endothelial dysfunction, which impairs the production of vasodilators along with an overexpression of vasoconstrictors [2]. This imbalance towards vasoconstriction further promotes vascular remodeling. The initial harmful stimulus leading to this deleterious process of endothelial dysfunction and vascular remodeling in $\mathrm{PH}$ is still incompletely understood. Possible factors are inflammation, some forms of infection and hypoxia, all most probably on a genetic background of increased susceptibility and aggravated by hitherto unknown environmental risk factors [3]. The penetrance of $\mathrm{PH}$ in families with a mutation of the bone morphogenetic protein type II receptor is low and the mutation is seldom found in other forms of $\mathrm{PH}$. Thus, in addition to a genetic predisposition and associated disease, environmental factors may play a pathogenic role. Animal studies have shown that tobacco smoke exposure can lead to pulmonary endothelial dysfunction and plexogenic $\mathrm{PH}[4,5]$, and some reports indicate that this might also be the case in humans $[6,7]$. In a single-center study, we recently showed a higher prevalence of smokers (former or current) in patients with pulmonary arterial hypertension $(\mathrm{PAH})$ compared to chronic thromboembolic $\mathrm{PH}(\mathrm{CTEPH})$ and healthy controls from the Swiss Health Survey (SHS) 2007 [8]. The present investigation aimed to extend these findings to $\mathrm{PH}$ patients in Austria and Germany.

\section{Patients and Methods}

This is an international, multicenter, observational, case-control study performed in seven referral centers for $\mathrm{PH}$ in Europe. From November 2008 to October 2012, during hospital visits or by telephone calls, patients with precapillary $\mathrm{PH}$ were systematically asked questions about their smoking exposure and habits. Patients were divided into smokers (who ever smoked more than 1 packet of cigarettes for over 1 year, $\geq 1 \mathrm{PY}$ ), current smokers and nonsmokers. Non-smokers were additionally divided into passive smokers (defined as having been exposed to secondhand smoke for $>1$ h a day $>1$ year) and not exposed. Diagnosis of precapillary $\mathrm{PH}$ was made according to international criteria and guidelines by a thorough investigation, including right heart catheterization, computed tomography of the chest, a ventilation-perfusion scan, a pulmonary function test, blood gases, blood values and other exams as appropriate $[1,9]$. Inclusion criteria were pulmonary artery

Tobacco Smoke Exposure in PAH and Thromboembolic PH pressure $\geq 25 \mathrm{~mm} \mathrm{Hg}$ and pulmonary artery wedge pressure $\leq 15$ $\mathrm{mm} \mathrm{Hg}$. Patients with concomitant chronic lung diseases (WHO group III) and other relevant comorbidities (WHO group V) were excluded from the analysis. Some of the patients recruited in $\mathrm{Zu}$ rich participated in a first comparable study [8]; they were re-asked during follow-up visits and their data re-analyzed by a different team during the present survey. In addition to tobacco exposure, $\mathrm{PH}$ classification and clinical and hemodynamic data were noted and analyzed.

As a control group we used data from 18,747 presumably healthy participants of the SHS performed in 2007. Data retrieval for this survey was by telephone call [8].

\section{Statistical Analysis}

The comparison of prevalence rates of smoking exposure between our study population and the controls was performed using the $\chi^{2}$ test. Quantitative variable differences in patients and disease characteristics were compared using the Mann-Whitney U test. Smoking exposure differences in subgroups of the study populations were calculated by the $\chi^{2}$ test.

\section{Ethics}

All patients gave their written informed consent to register their data for scientific purposes and the study was approved by the local ethical authorities of each participating center. It was also registered at ClinicalTrials.gov (NCT01484899).

\section{Results}

\section{Patients}

Data of 533 precapillary $\mathrm{PH}$ patients (62\% women, mean age $62 \pm 14$ years) from Switzerland (42\%), Germany (52\%) and Austria (6\%) were prospectively enrolled. The majority of patients were classified as PAH (64\%), from which 60\% were idiopathic and 40\% were associated PAH. CTEPH was found in $24 \%$ of cases. A minority of cases had severe $\mathrm{PH}$ associated with chronic lung disease or miscellaneous ( 8 and 3\%, respectively) and were excluded from further analysis due to the known association between tobacco smoke exposure and chronic lung diseases and unknown pathogenesis in miscellaneous forms. The patient characteristics of the 472 patients with PAH or CTEPH are summarized in table 1.

\section{Overall Tobacco Smoke Exposure by Gender}

Of these 472 patients with PAH and CTEPH, 233 (49\%) were smokers and they demonstrated a clear sex difference ( $37 \%$ of women, $71 \%$ of men, $\mathrm{p}<0.00001$; table 2). Fifty-two (11\%) PH patients were persistent smokers ( $9 \%$ of women, $15 \%$ of men, $\mathrm{p}=0.06)$. Patients started smoking at an average age of $20 \pm 6$ years (women $19 \pm 4$, men $20 \pm 8, \mathrm{p}=0.63)$ and stopped with $43 \pm 14$ years (women $39 \pm 14$, men $47 \pm 13, p=0.0001$ ). On average, 
Table 1. Patient characteristics

\begin{tabular}{lc}
\hline Patients, $\mathrm{n}$ & \\
Female patients, $\mathrm{n}$ & 472 \\
Age at diagnosis, years & 301 \\
BMI & $57 \pm 16$ \\
PH class & $26.9 \pm 5.6$ \\
$\quad$ PH group I & $342(72)$ \\
$\quad$ Idiopathic & $204(43)$ \\
$\quad$ Associated & $138(29)$ \\
$\quad$ PH group IV & $130(28)$ \\
WHO functional class & \\
$\quad$ Class I + II & $84(21)$ \\
$\quad$ Class III & $257(63)$ \\
$\quad$ Class IV & $65(16)$ \\
6MWD, m & $373 \pm 118$ \\
Echocardiographic LV ejection fraction, \% & $62 \pm 8$ \\
Tricuspid pressure gradient, mm Hg & $65 \pm 20$ \\
mPAP, mm Hg & $46 \pm 1$ \\
Pulmonary artery occlusion pressure, mm Hg & $9.5 \pm 4.6$ \\
Pulmonary vascular resistance, Wood units & $9.84 \pm 5.34$ \\
Cardiac index, l/min/m ${ }^{2}$ & $2.4 \pm 0.7$ \\
Mixed venous oxygen saturation, \% & $62 \pm 10$ \\
Arterial oxygen saturation, \% & $91 \pm 5$ \\
FEV, \% predicted & $83 \pm 19$ \\
FVC, \% predicted & $88 \pm 21$ \\
FEV $/$ FVC & $78 \pm 11$ \\
D $_{\text {LCO, \% predicted }}$ & $62 \pm 21$ \\
\hline & \\
\hline &
\end{tabular}

Data are presented as the mean $\pm \mathrm{SD}$, or number with percentage in parentheses. $6 \mathrm{MWD}=6$-Min walking distance; $\mathrm{LV}=$ left ventricular.

PH smokers smoked $22 \pm 20$ PY (males $28 \pm 22$, females $16 \pm 16, \mathrm{p}<0.0001)$.

From the 239 included $\mathrm{PH}$ patients who were not active smokers, $114(48 \%)$ were exposed to secondhand smoke (50\% of women, $40 \%$ of men, $\mathrm{p}=0.22$ ) for an average time of $19 \pm 13$ years (women $20 \pm 12$, men $19 \pm 17$, $\mathrm{p}=0.32$ ). Thus, $74 \%$ of the $\mathrm{PH}$ collective had ever been exposed to tobacco smoke, $49 \%$ were active smokers and $24 \%$ were exposed to secondhand smoke.

\section{Comparison to Healthy Controls}

In comparison to healthy controls, smokers were less frequently found among $\mathrm{PH}$ women ( 37 vs. $43 \%, \mathrm{p}=$ 0.042 ) but more frequently found among $\mathrm{PH}$ men (71 vs. $57 \%, \mathrm{p}=0.0007$; table 2 ). Both $\mathrm{PH}$ women and men were significantly less persistent smokers compared to the healthy controls (women 9 vs. $24 \%, \mathrm{p}<0.0001$; men 15 vs. $32 \%, \mathrm{p}<0.0001)$. However, $\mathrm{PH}$ women and men were significantly more frequently exposed to secondhand smoke (women 50 vs. $14 \%, \mathrm{p}<0.0001$; men 40 vs. $27 \%$, $\mathrm{p}<0.0001$ ), resulting in a higher overall exposure to tobacco smoke in $\mathrm{PH}$ compared with controls (women 68 vs. $51 \%, \mathrm{p}<0.0001$; men 82 vs. $69 \%, \mathrm{p}=0.0002)$.

\section{Differential Tobacco Smoke Exposure for $P A H$ and CTEPH}

The prevalence of tobacco smoke exposure for PAH and CTEPH is shown in table 3. For both sexes, the percentage of smokers was higher in PAH compared with CTEPH (women 40 vs. $29 \%$, men 75 vs. $64 \%$ ), but the differences were statistically not significant. A significantly higher percentage of female smokers compared to CTEPH women could only be detected in the group of associated PAH $(\mathrm{p}=0.0447)$.

No significant differences in secondhand smoke exposure were found between non-smoking CTEPH and PAH patients, neither in men nor in women. The age of quitting smoking in $\mathrm{PAH}$ women was significantly higher compared to CTEPH women $(41 \pm 15$ vs. $33 \pm 11$ years, $\mathrm{p}=0.0267$ ), whereas in men there was no difference between these groups. CTEPH women were significantly younger at diagnosis of $\mathrm{PH}$ than $\mathrm{PAH}$ women ( $45 \pm 11$ vs. $54 \pm 13$ years, $\mathrm{p}=0.001$ ).

$\mathrm{PAH}$ men showed a significantly longer total exposure to tobacco smoke compared to CTEPH men when taking active smoking calculated as cumulative pack years and the duration of passive tobacco smoke exposure together ( $36 \pm 25$ vs. $25 \pm 21 \mathrm{PY}, \mathrm{p}=0.0073$ ). Overall, there seems be a stronger association between tobacco smoke exposure and PAH than CTEPH since the incidence of male smokers in $\mathrm{PAH}$ is significantly higher, the incidence of environmental smoke exposure in $\mathrm{PAH}$ women is higher, and there seems to be a trend toward a higher incidence of female smokers in PAH compared to CTEPH.

\section{Differential Characteristics for Smokers and \\ Non-Smokers}

Smokers among $\mathrm{PH}$ women and men were significantly younger compared to those not exposed (women $52 \pm$ 13 vs. $58 \pm 18$ years, $\mathrm{p}=0.0051$; men $57 \pm 15$ vs. $64 \pm 17$ years, $\mathrm{p}=0.0288$ ). Women who smoked were significantly younger at diagnosis than men who smoked ( $\mathrm{p}=$ 0.0062 ). Detailed differential characteristics are listed in table 4.

Female smokers had a higher right atrial pressure, and lower mixed venous oxygen saturation and forced expiratory volume in $1 \mathrm{~s} /$ forced vital capacity $\left(\mathrm{FEV}_{1} / \mathrm{FVC}\right)$ ratio, and males had a lower diffusion capacity for carbon monoxide compared to those not exposed. Women exposed to secondhand smoke had a lower $\mathrm{FEV}_{1} / \mathrm{FVC}$ compared 
Table 2. Prevalence and quantity of tobacco smoke exposure

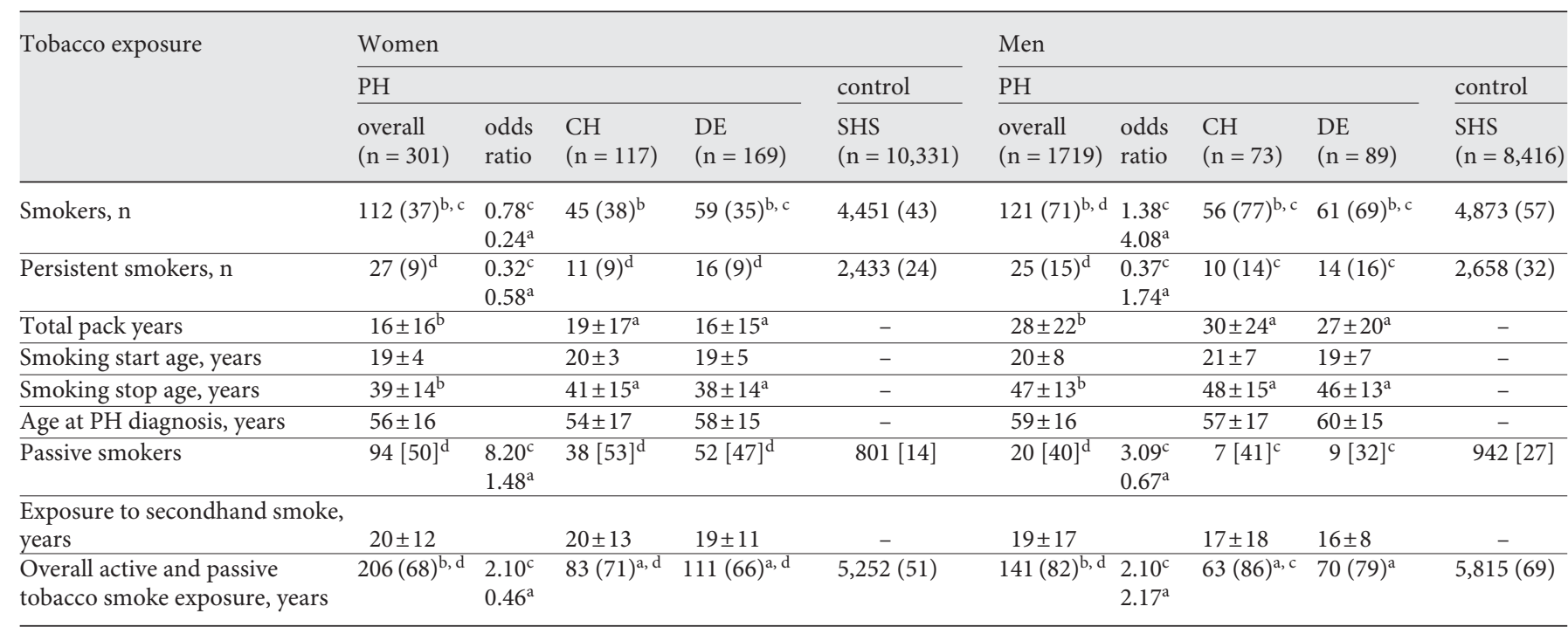

Data are presented as the mean $\pm \mathrm{SD}$, or number with percentages in parentheses; values in square brackets are percentages of non-smokers. $\mathrm{CH}=$ Switzerland; DE = Germany. Difference between genders: ${ }^{\mathrm{a}} \mathrm{p}<0.05,{ }^{\mathrm{b}} \mathrm{p}<0.001$. Difference to Swiss control group SHS: ${ }^{\mathrm{c}} \mathrm{p}<0.05,{ }^{\mathrm{d}} \mathrm{p}<0.001$.

to non-exposed PH women. Secondhand smoke exposure in men was significantly associated with a lower mixed venous oxygen saturation compared to those not exposed.

\section{Discussion}

To our knowledge, this is the first major, international, multicenter prospective survey on tobacco smoke exposure in patients with PAH and CTEPH living in three European countries. The main findings of this multicenter study are that overall about half of $\mathrm{PH}$ patients were smokers, with a clear sex difference of $37 \%$ of female and $71 \%$ of male smokers. Significantly more $\mathrm{PH}$ men were smokers compared with healthy men, whereas less $\mathrm{PH}$ women were ever active smokers compared to their healthy counterparts. However, $50 \%$ of the non-smoking $\mathrm{PH}$ women were exposed to secondhand smoke, leading to an overall number of tobacco smoke-exposed individuals, either as active smokers or through environmental tobacco smoke exposure, which was significantly higher compared to healthy controls [10]. PH smokers were significantly younger compared to the non-exposed, and female $\mathrm{PH}$ smokers, even though smoking less pack years, were significantly younger than male $\mathrm{PH}$ smokers. PAH men showed a significantly higher cumulative tobacco smoke exposure, taking active smoking and environmental smoke exposure together, than CTEPH men.

Since the 1960s it has been known from animal experiments that tobacco smoke inhalation leads to immediate and temporary elevation of the pulmonary arterial pressure. This has been shown in dogs, frogs, rabbits, cats, rats and guinea pigs [11], and animal models of guinea pigs and rats exposed to tobacco smoke were used to study $\mathrm{PH}$ and the vasoproliferative response $[12,13]$. Our findings of a significantly higher smoking prevalence in $\mathrm{PH}$ men and significantly more $\mathrm{PH}$ women exposed to tobacco smoke (either active smokers or environmental exposure) may point towards a possible noxious effect of tobacco smoke constituents on the pulmonary vasculature in human beings as well. These noxious stimuli in combination or accumulation with other hits may contribute to pulmonary vasoproliferation and, ultimately, $\mathrm{PH}$. In animal models it could be shown that tobacco smoke inhalation leads to an early elevation of pulmonary arterial pressure, long before destruction of the lung parenchyma [12]. This could also be demonstrated in human studies $[7,14,15]$. Tobacco smoke exposure also induced cell proliferation of smooth muscle cells of the vasculature $[13,16]$, led to infiltration of inflammatory cells, and gene expression with overproduction of different mediators responsible for cell proliferation and vasomotor regulation, namely inducible nitric oxide synthase [17], endo- 


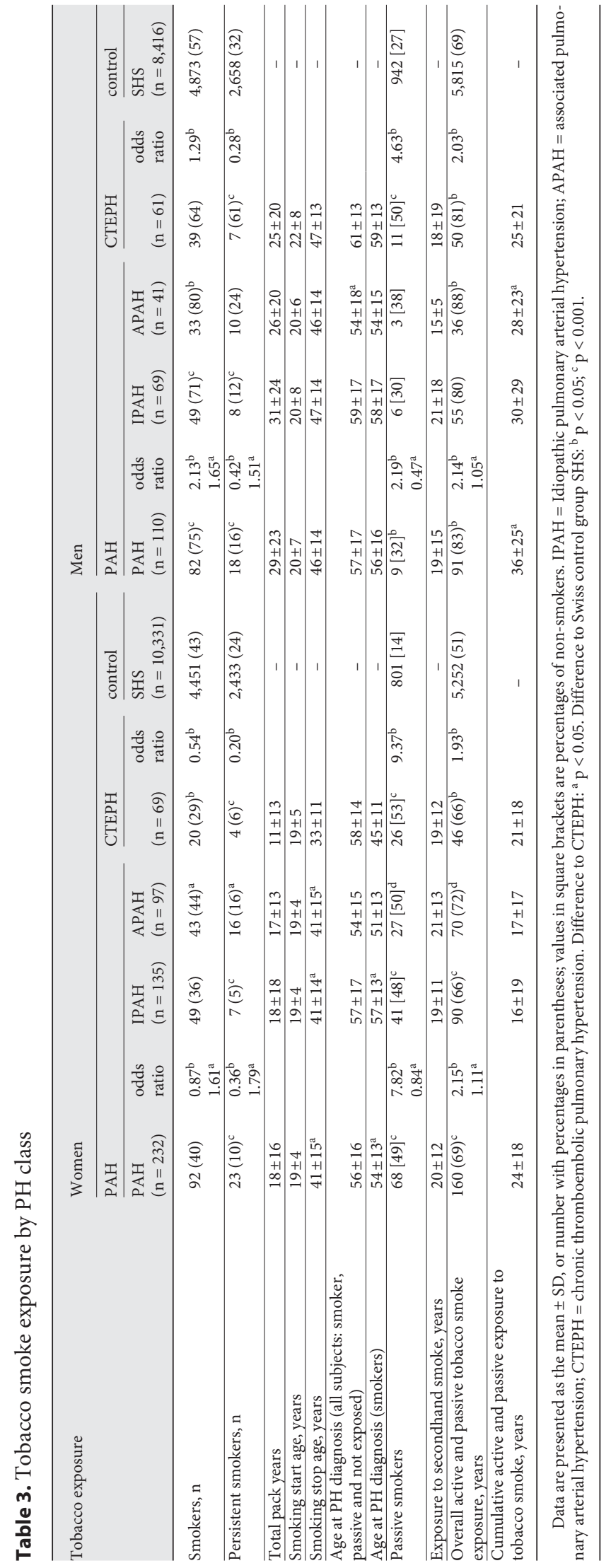

thelin [4], vascular endothelial growth factor (VEGF), platelet-derived growth factor (PDGF) and others [18]. The alterations lead to endothelial dysfunction of the pulmonary vasculature [19]. In PAH patients, similar inflammatory processes with disturbances in endothelial and smooth muscle cell function, overexpression of growth factors (PDGF, VEGF, fibroblast growth factor) and an unbalance in vasodilators and vasoconstrictors (endothelin 1, serotonin, thromboxane A2, nitric oxide, prostacyclin) are prominent.

We are well aware that translation of evidence based on animal experiments into human pathophysiology is more than complicated. Nevertheless, there already exists some evidence resulting from human studies that support a noxious role of tobacco smoke exposure in the human vasculature that is comparable to animal models: in newborns suffering from persistent $\mathrm{PH}$, high levels of cotinine as a marker of maternal tobacco smoke exposure could be measured [20]. Impaired vessel structure and function, inflammatory infiltrates with CD8+ T lymphocytes, vascular muscular hyperplasia and intimal thickening has been reported in patients with $\mathrm{PH}$ and chronic obstructive pulmonary disease (COPD) $[7,15]$. In smokers, expression of endothelial nitric oxide synthase is reduced and the pulmonary vasculature shows endothelial dysfunction [6].

In the present study we found a high prevalence of environmental smoke-exposed $\mathrm{PH}$ women. The adverse health effects of environmental smoke exposure are well known. An increase in inflammatory markers such as L-1 $\beta$, IL-4, TNF- $\alpha$, white blood cell count, C-reactive protein, homocysteine, fibrinogen, as well as leukocyte counts accompanied by an immune cell activation has been shown [21,22]. Besides this, a greater decline in lung function, elevated risk of cardiovascular mortality and induction of growth factors (connective tissue growth factor, TGF- $\beta$, PDGF-A and B) are also known $[23,24]$. Whether some reactions to inhalation of environmental tobacco smoke or tobacco smoke in general triggers vascular remodeling, similar to that seen in vasoproliferative $\mathrm{PAH}$, is speculative and should be interpreted with caution. Our findings of a higher prevalence of secondhand smoke-exposed $\mathrm{PH}$ women and the higher prevalence of overall tobacco smoke exposure (smokers and passive smokers) compared to healthy controls might point towards a noxious role of tobacco smoke on the pulmonary vasculature.

It may well be that there exists a sex difference in terms of a greater susceptibility of women who are exposed to tobacco smoke compared with men. Similar sex differ- 
Table 4. Differential characteristics of smokers, passive smokers and non-smokers

\begin{tabular}{|c|c|c|c|c|c|c|}
\hline $1+2$ & $16(16)$ & $16(20)$ & $18(22)$ & $28(26)$ & $3(25)$ & $3(14)$ \\
\hline 3 & $66(66)$ & $54(66)$ & $52(63)$ & $61(57)$ & $7(58)$ & $17(77)$ \\
\hline Heart rate, bpm & $80 \pm 13^{\mathrm{a}}$ & $78 \pm 12$ & $81 \pm 15^{\mathrm{a}}$ & $77 \pm 13^{\mathrm{a}}$ & $80 \pm 16$ & $72 \pm 13^{\mathrm{a}}$ \\
\hline Mean systemic arterial pressure, $\mathrm{mm} \mathrm{Hg}$ & $95 \pm 14$ & $95 \pm 17$ & $92 \pm 18$ & $92 \pm 15$ & $97 \pm 14$ & $98 \pm 15$ \\
\hline $\mathrm{mPAP}, \mathrm{mm} \mathrm{Hg}$ & $47 \pm 13$ & $44 \pm 14$ & $46 \pm 15$ & $46 \pm 12$ & $44 \pm 13$ & $46 \pm 16$ \\
\hline Pulmonary vascular resistance, Wood units & $10.2 \pm 5.7$ & $9.7 \pm 5.9$ & $10.9 \pm 5.2$ & $9.3 \pm 5.1$ & $8.9 \pm 3.9$ & $8.7 \pm 4.1$ \\
\hline Right atrial pressure, $\mathrm{mm} \mathrm{Hg}$ & $8.5 \pm 5.2^{\mathrm{c}}$ & $7.6 \pm 4.9$ & $6.7 \pm 4.7^{\mathrm{a}}$ & $8.1 \pm 5.0$ & $7.8 \pm 5.3$ & $9.3 \pm 5.1^{\mathrm{a}}$ \\
\hline Arterial oxygen saturation, $\%$ & $92.0 \pm 4.3$ & $91.1 \pm 7.7$ & $92.2 \pm 4.1$ & $90.8 \pm 5.8$ & $90.3 \pm 4.6$ & $92.1 \pm 5.3$ \\
\hline $\mathrm{D}_{\mathrm{LCO}}, \%$ & $62 \pm 19$ & $66 \pm 21$ & $61 \pm 19$ & $60 \pm 22^{c}$ & $65 \pm 25$ & $68 \pm 23$ \\
\hline
\end{tabular}

Data are presented as the mean $\pm \mathrm{SD}$, or number with percentages in parentheses. $6 \mathrm{MWD}=6$-Min walking distance. Difference between genders: ${ }^{a} \mathrm{p}<0.05$. Difference to passive smokers: ${ }^{\mathrm{b}} \mathrm{p}<0.05$. Difference to not exposed: ${ }^{\mathrm{c}} \mathrm{p}<0.05$.

ences to tobacco smoke exposure have been shown for lung cancer [25]. A higher susceptibility could perhaps explain the lower active but higher secondhand smoke exposure in $\mathrm{PH}$ women. If predisposed women, for example those who are genetically more susceptible due to alterations in genes responsible for $\mathrm{PAH}$, such as BMPR2 mutations, are exposed to constituents of tobacco smoke, a lower cumulative dose might be sufficient to initiate pulmonary vascular remodeling, ultimately leading to $\mathrm{PH}$. Potential sex differences in COPD are discussed in the literature [26-28], and it could be shown that $\mathrm{PH}$ is more frequent in female COPD patients [29].

In a well-designed recent study, a possible $\mathrm{PAH}$ phenotype was characterized which showed worse exercise performance and survival [30]. Characteristics of that phenotype are low diffusing capacity for carbon monoxide (DLCO; <45\%), male gender, higher tobacco smoke exposure and slightly lower lung function in terms of $\mathrm{FEV}_{1}, \mathrm{FEV}_{1} / \mathrm{FVC}$ and total lung capacity. No correlation to hemodynamic status was seen. Our data is in line with these findings since we found that $\mathrm{PH}$ was associated with tobacco smoke exposure in a relevant proportion of patients and we also found slightly lower than predicted lung function values in our collective. However, in contrast, the mean diffusion capacity was not severely re-

Tobacco Smoke Exposure in PAH and Thromboembolic PH duced in our patients (mean DLCO 62\%, 49-77) compared with the depicted subgroup by Trip et al. [30] with a DLCO $<45 \%$.

The present study has the following limitations. First, we cannot exclude a selection bias. Although all centers systematically included consecutive $\mathrm{PH}$ patients, we cannot exclude that some $\mathrm{PH}$ patients were missing in the present analysis due to logistics or for time reasons. Second, as this survey was based on questions regarding tobacco smoke exposure, patients may not have remembered every detail of the amount and timely sequence of tobacco smoke exposure, resulting in a declaration bias of smoking history or exposure to environmental tobacco smoke. However, a similar declaration bias might be found in the healthy controls. We cannot exclude that sick individuals search for a causal explanation for their illness and, thus, their reported smoke exposure might be exaggerated. Third, the mean lung volumes in the present cohort were relatively low $\left(\mathrm{FEV}_{1} 83 \pm 19\right.$ and FVC $88 \pm$ $21 \%$ ) and one could speculate about underlying structural lung disease. However, low lung volumes have been shown for different $\mathrm{PH}$ collectives, some with concomitant dynamic hyperinflation mechanical constraints [31, 32]. One could also argue that, consistent with the animal experiments, in some patients after a short exposure time 
tobacco smoke exposition leads to changes in the pulmonary vasculature before noticeable destruction of the lung parenchyma, without a progressive increase in pulmonary arterial pressures even after lung destruction becomes manifest [12]. With half of $\mathrm{PH}$ patients being smokers, some might have intrinsically smoke-related lung disease with alterations in the pulmonary vessels but not yet in the airways. The fact that $\mathrm{PH}$ in COPD characteristically shows mild elevations in pulmonary arterial pressures usually not exceeding $30-35 \mathrm{~mm} \mathrm{Hg}[33,34]$ and that in our study $82 \%$ of all smokers showed a high $\mathrm{mPAP}$ of $>35 \mathrm{~mm} \mathrm{Hg}$ strongly discourages airway disease as being the major cause of $\mathrm{PH}$ in our collective. Furthermore, it has to be mentioned that our study includes incident and prevalent cases that cause a lead time bias. Incident cases, presumably showing a phenotype with worse prognosis, may have already disappeared by the time of conducting the study, creating an overweight of prevalent cases with better prognosis and weaker association or sensibility to tobacco smoke as the offending agent.

In summary, we could herein show that a history of active or environmental tobacco smoke exposure is highly prevalent in $\mathrm{PH}$ patients. Supported by experimental data from animal models and evidence of inflammation and endothelial dysfunction in humans as a response to tobacco smoke exposure, these data may indicate that tobacco smoke and its constituents are, among various other factors, involved in the pathogenesis of human $\mathrm{PH}$, perhaps in terms of a second hit to genetically susceptible individuals. These findings are important for $\mathrm{PH}$ patients and their caregivers, as early counselling and protection may prevent disease manifestation in relatives or patients at risk.

\section{Conclusion}

Tobacco smoke exposure is common in $\mathrm{PH}$ : over one third of $\mathrm{PH}$ women and two thirds of $\mathrm{PH}$ men were active smokers. Strikingly, $10-15 \%$ of $\mathrm{PH}$ patients are persistent smokers and half of the non-smoking $\mathrm{PH}$ women were exposed to secondhand smoke. The higher prevalence of male PH smokers, the significantly higher exposure to environmental tobacco smoke in $\mathrm{PH}$ women compared to healthy subjects, and the lower age at $\mathrm{PH}$ diagnosis in smokers may indicate that tobacco smoke exposure deteriorates $\mathrm{PH}$, that it might be involved as a second hit in the pathogenesis of $\mathrm{PH}$, and that women may be more susceptible to the constituents of tobacco smoke.

\section{Acknowledgements}

We thank the PH nurses of all centers for their excellent data collection. S. Ulrich is funded by a grant from the Swiss National Science Foundation and the Zurich Lung League, which partly funded the reported study.

\section{Financial Disclosure and Conflicts of Interest}

No conflicts of interests regarding this study are declared by the authors.

\section{References}

- 1 Simonneau G, Robbins IM, Beghetti M, Channick RN, Delcroix M, Denton CP, Elliott CG, Gaine SP, Gladwin MT, Jing ZC, Krowka MJ, Langleben D, Nakanishi N, Souza R: Updated clinical classification of pulmonary hypertension. J Am Coll Cardiol 2009;54:S43S54.

-2 Eddahibi S, Morrell N, d'Ortho MP, Naeije R, Adnot S: Pathobiology of pulmonary arterial hypertension. Eur Respir J 2002;20:15591572.

-3 Ulrich S, Hersberger M, Fischler M, Nussbaumer-Ochsner Y, Treder U, Russi EW, Speich R: Genetic polymorphisms of the serotonin transporter, but not the 2a receptor or nitric oxide synthetase, are associated with pulmonary hypertension in chronic obstructive pulmonary disease. Respiration 2010;79:288-295.
4 Wright JL, Tai H, Churg A: Cigarette smoke induces persisting increases of vasoactive mediators in pulmonary arteries. Am J Respir Cell Mol Biol 2004;31:501-509.

-5 Wright JL, Farmer SG, Churg A: A neutrophil elastase inhibitor reduces cigarette smoke-induced remodelling of lung vessels. Eur Respir J 2003;22:77-81.

-6 Barbera JA, Peinado VI, Santos S, Ramirez J, Roca J, Rodriguez-Roisin R: Reduced expression of endothelial nitric oxide synthase in pulmonary arteries of smokers. Am J Respir Crit Care Med 2001;164:709-713.

7 Santos S, Peinado VI, Ramirez J, Melgosa T, Roca J, Rodriguez-Roisin R, Barbera JA: Characterization of pulmonary vascular remodelling in smokers and patients with mild COPD. Eur Respir J 2002;19:632-638.
8 Schiess R, Senn O, Fischler M, Huber LC Vatandaslar S, Speich R, Ulrich S: Tobacco smoke: a risk factor for pulmonary arterial hypertension? A case-control study. Chest 2010; 138:1086-1092.

-9 Grunig E, Barner A, Bell M, Claussen M, Dandel M, Dumitrescu D, Gorenflo M, Holt S, Kovacs G, Ley S, Meyer JF, Pabst S, Riemekasten G, Saur J, Schwaiblmair M, Seck C, Sinn L, Sorichter S, Winkler J, Leuchte HH: Noninvasive diagnosis of pulmonary hypertension: ESC/ERS Guidelines with commentary of the Cologne Consensus Conference 2010 (in German). Dtsch Med Wochenschr 2010; 135(suppl 3):S67-S77. 
10 Jha P, Ramasundarahettige C, Landsman V, Rostron B, Thun M, Anderson RN, McAfee T, Peto R: 21st-century hazards of smoking and benefits of cessation in the United States. N Engl J Med 2013;368:341-350.

-11 Samanek M, Aviado DM: Cardiopulmonary effects of tobacco and related substances. 3 . Pulmonary vascular effects of cigarette smoke and nicotine. Arch Environ Health 1966;12: 717-724.

12 Wright JL, Churg A: Effect of long-term cigarette smoke exposure on pulmonary vascular structure and function in the guinea pig. Exp Lung Res 1991;17:997-1009.

13 Sekhon HS, Wright JL, Churg A: Cigarette smoke causes rapid cell proliferation in small airways and associated pulmonary arteries. Am J Physiol 1994;267:L557-L563.

14 Hale KA, Ewing SL, Gosnell BA, Niewoehner DE: Lung disease in long-term cigarette smokers with and without chronic air-flow obstruction. Am Rev Respir Dis 1984;130: 716-721.

15 Peinado VI, Barbera JA, Abate P, Ramirez J, Roca J, Santos S, Rodriguez-Roisin R: Inflammatory reaction in pulmonary muscular arteries of patients with mild chronic obstructive pulmonary disease. Am J Respir Crit Care Med 1999;159:1605-1611.

16 Yamato H, Sun JP, Churg A, Wright JL: Guinea pig pulmonary hypertension caused by cigarette smoke cannot be explained by capillary bed destruction. J Appl Physiol 1997;82: 1644-1653.

17 Seimetz M, Parajuli N, Pichl A, Veit F, Kwapiszewska G, Weisel FC, Milger K, Egemnazarov B, Turowska A, Fuchs B, Nikam S, Roth M, Sydykov A, Medebach T, Klepetko W, Jaksch P, Dumitrascu R, Garn H, Voswinckel R, Kostin S, Seeger W, Schermuly RT, Grimminger F, Ghofrani HA, Weissmann N: Inducible NOS inhibition reverses tobaccosmoke-induced emphysema and pulmonary hypertension in mice. Cell 2011;147:293-305.
8 Wright JL, Tai H, Churg A: Vasoactive mediators and pulmonary hypertension after cigarette smoke exposure in the guinea pig. J Appl Physiol 2006;100:672-678.

19 Wright JL, Churg A: Short-term exposure to cigarette smoke induces endothelial dysfunction in small intrapulmonary arteries: analysis using guinea pig precision cut lung slices. J Appl Physiol 2008;104:1462-1469.

20 Bearer C, Emerson RK, O’Riordan MA, Roitman E, Shackleton C: Maternal tobacco smoke exposure and persistent pulmonary hypertension of the newborn. Environ Health Perspect 1997; 105:202-206.

21 Flouris AD, Vardavas CI, Metsios GS, Tsatsakis AM, Koutedakis Y: Biological evidence for the acute health effects of secondhand smoke exposure. Am J Physiol Lung Cell Mol Physiol 2010;298:L3-L12.

22 Hamer M, Stamatakis E, Kivimaki M, Lowe GD, Batty GD: Objectively measured secondhand smoke exposure and risk of cardiovascular disease: what is the mediating role of inflammatory and hemostatic factors? J Am Coll Cardiol 2010;56:18-23.

23 Eisner MD, Wang Y, Haight TJ, Balmes J, Hammond SK, Tager IB: Secondhand smoke exposure, pulmonary function, and cardiovascular mortality. Ann Epidemiol 2007;17: 364-373.

24 Churg A, Wang RD, Wright JL: Cigarette smoke causes small airway remodeling by direct growth factor induction and release. Proc Am Thorac Soc 2006;3:493.

25 Zang EA, Wynder EL: Differences in lung cancer risk between men and women: examination of the evidence. J Natl Cancer Inst 1996;88:183-192.

26 Kirkpatrick dP, Dransfield MT: Racial and sex differences in chronic obstructive pulmonary disease susceptibility, diagnosis, and treatment. Curr Opin Pulm Med 2009;15:100104.
27 Sin DD, Cohen SB, Day A, Coxson H, Pare PD: Understanding the biological differences in susceptibility to chronic obstructive pulmonary disease between men and women. Proc Am Thorac Soc 2007;4:671-674.

28 Ben-Zaken Cohen S, Pare PD, Man SF, Sin DD: The growing burden of chronic obstructive pulmonary disease and lung cancer in women: examining sex differences in cigarette smoke metabolism. Am J Respir Crit Care Med 2007;176:113-120.

-29 Sertogullarindan B, Gumrukcuoglu HA, Sezgi C, Akil MA: Frequency of pulmonary hypertension in patients with COPD due to biomass smoke and tobacco smoke. Int J Med Sci 2012;9:406-412.

30 Trip P, Nossent EJ, de Man FS, van den Berk IA, Boonstra A, Groepenhoff H, Leter EM, Westerhof N, Grunberg K, Bogaard HJ, Vonk Noordegraaf A: Severely reduced diffusion capacity in idiopathic pulmonary arterial hypertension - patient characteristics and treatment responses. Eur Respir J 2013;42:15751585.

-31 Laveneziana P, Garcia G, Joureau B, NicolasJilwan F, Brahimi T, Laviolette L, Sitbon O, Simonneau G, Humbert M, Similowski T: Dynamic respiratory mechanics and exertional dyspnoea in pulmonary arterial hypertension. Eur Respir J 2013;41:578-587.

32 Meyer FJ, Ewert R, Hoeper MM, Olschewski $\mathrm{H}$, Behr J, Winkler J, Wilkens H, Breuer C, Kubler W, Borst MM: Peripheral airway obstruction in primary pulmonary hypertension. Thorax 2002;57:473-476.

-33 Chaouat A, Naeije R, Weitzenblum E: Pulmonary hypertension in COPD. Eur Respir J 2008;32:1371-1385.

34 Chaouat A, Bugnet AS, Kadaoui N, Schott R, Enache I, Ducolone A, Ehrhart M, Kessler R, Weitzenblum E: Severe pulmonary hypertension and chronic obstructive pulmonary disease. Am J Respir Crit Care Med 2005; 172 189-194.
Tobacco Smoke Exposure in PAH and Thromboembolic PH 